\title{
Systematic Review \\ Aromatase and CDK4/6 Inhibitor-Induced Musculoskeletal Symptoms: A Systematic Review
}

\author{
Angeliki Andrikopoulou ${ }^{1,2}$, Oraianthi Fiste ${ }^{1,2} \mathbb{D}$, Michalis Liontos ${ }^{1,2}$, Meletios-Athanasios Dimopoulos ${ }^{1,2} \mathbb{D}$ \\ and Flora Zagouri 1,2,*
}

check for

updates

Citation: Andrikopoulou, A.; Fiste, O.; Liontos, M.; Dimopoulos, M.-A.; Zagouri, F. Aromatase and CDK4/6 Inhibitor-Induced Musculoskeletal Symptoms: A Systematic Review. Cancers 2021, 13, 465. https:// doi.org/10.3390/cancers13030465

Received: 14 November 2020

Accepted: 21 January 2021

Published: 26 January 2021

Publisher's Note: MDPI stays neutral with regard to jurisdictional claims in published maps and institutional affiliations.

Copyright: (c) 2021 by the authors. Licensee MDPI, Basel, Switzerland. This article is an open access article distributed under the terms and conditions of the Creative Commons Attribution (CC BY) license (https:// creativecommons.org/licenses/by/ $4.0 /)$.
1 Department of Clinical Therapeutics, Alexandra Hospital, Medical School, 11528 Athens, Greece; aggandrikop@med.uoa.gr (A.A.); ofiste@med.uoa.gr (O.F.); mlionto@med.uoa.gr (M.L.); mdimop@med.uoa.gr (M.-A.D.)

2 Medical School, National and Kapodistrian University of Athens, 80 Vasilissis Sofias Avenue, 11528 Athens, Greece

* Correspondence: fzagouri@med.uoa.gr or florazagouri@yahoo.co.uk; Tel.: +30-21-0338-1554; Fax: +30-21-3216-2511

Simple Summary: Aromatase inhibitor-induced musculoskeletal symptoms (AIMSS) occurs in up $50 \%$ of postmenopausal patients and is the reason for treatment discontinuation in $25 \%$ of patients with breast cancer. CDK4/ 6 inhibitors have been established in the treatment of hormone receptorpositive (HR) breast cancer. We aimed to assess the effect of treatment with CDK4/ 6 inhibitors on AIMSS. Arthralgia rate was lower in patients receiving aromatase inhibitors (AIs) in combination with CDK4/ 6 inhibitors (5.8-33.3\%) compared with monotherapy with AIs (1-47\%). Myalgias, back pain and bone pain also tended to be reduced in patients treated with CDK4/6 inhibitors. CDK4/6 inhibitors may alleviate musculoskeletal pain caused by AIs, although further studies are warranted.

Abstract: Background: Treatment with aromatase inhibitors (AIs) is fundamental in women with hormone receptor-positive breast cancer in the adjuvant as well as the metastatic setting. Even though it is considered to be a well-tolerated therapy, aromatase inhibitor-associated musculoskeletal syndrome (AIMSS) is the most common adverse event encountered by breast cancer patients. CDK4/ 6 inhibitors have emerged as a new treatment strategy in metastatic hormone receptor-positive breast cancer. However, the impact of CDK4/6 inhibitors on musculoskeletal symptoms caused by AIs is not well-defined. Objectives: This systematic review aims to identify the frequency of joint symptoms induced by treatment with AIs and CDK4/6 inhibitors in the metastatic setting. Search strategy: Eligible articles were identified by a search of existing literature for the period 2005/01/01-2021/01/01; The algorithm consisted of a predefined combination of the following keywords "breast", "cancer", "aromatase inhibitors", “CDK4/6", "phase III". Selection criteria: This study was performed in accordance with PRISMA guidelines. All randomized controlled Phase III trials (RCTs) evaluating the administration of third-generation aromatase inhibitors (AIs) and CDK4/6 inhibitors in postmenopausal women in the metastatic setting were considered eligible for this review. Data collection: Overall, 16 randomized control trials (RCTs) were retrieved, of which nine studies explored the administration of AIs in the metastatic setting and seven studies investigated the combination of CDK4/6 inhibitors and AIs. Arthralgia was reported in 1-47\% of patients treated with AIs and 5.8-33.3\% of patients treated with CDK4/6 inhibitors. Myalgias occurred in $2-23.7 \%$ of patients receiving AIs compared with $4.8-11.9 \%$ of patients treated with CDK4/ 6 inhibitors. The incidence of back pain was $7-32.9 \%$ vs. $2.9-8.5 \%$ in postmenopausal women with metastatic disease treated with AIs and CDK4/6 inhibitors, respectively. Bone pain was reported in $7-32.9 \%$ of postmenopausal women treated with AIs and $2.9-8.5 \%$ of women treated with CDK4/ 6 inhibitors. Conclusions: AI treatment-induced musculoskeletal syndrome is an adverse event affecting over one-third (20-47\%) of postmenopausal patients treated with AIs that often leads to treatment discontinuation. Data from RCTs provide evidence that the incidence of musculoskeletal symptoms is relatively decreased upon CDK4/6 inhibitor administration. CDK4/6 inhibitors may provide a protective role against AIMSS development. 
Keywords: breast; cancer; aromatase; CDK4/6 inhibitors; arthralgia; musculoskeletal

\section{Introduction}

Breast cancer is the most commonly diagnosed cancer type in women in both developed and developing countries. It is estimated that in 2020, 276,480 new cases and 42,170 new deaths will be reported in the United States, making breast cancer the second leading cause of cancer-related mortality in women [1]. Around $75 \%$ of all breast cancer cases express the estrogen receptor (ER) and/or the progesterone receptor (PgR) and are considered hormone receptor-positive (HR) tumors [2]. Women who present with early hormone receptor-positive breast cancer are treated with surgery and adjuvant endocrine therapy (ET), but metastatic disease eventually develops in up to $40 \%$ despite adjuvant treatment [3]. In addition, almost two-thirds of de novo metastatic breast cancer cases are hormone receptor-positive [4]. Consequently, endocrine therapy is the cornerstone of $\mathrm{H}$-positive disease treatment in both the adjuvant and metastatic setting. Third-generation aromatase inhibitors (AI), including letrozole, anastrozole and exemestane, are well established in the endocrine therapy of postmenopausal breast cancer patients. The recommended treatment approach for women in the adjuvant setting is aromatase inhibitor administration for a total of 5-10 years [5] as there are several trials confirming their superiority over treatment with tamoxifen [6,7]. However, despite the initial response to endocrine therapy, $25 \%$ of $\mathrm{H}$-positive early-stage breast cancer cases and almost all metastatic cases eventually develop resistance to treatment [8]. Currently, CDK4/ 6 inhibitors have emerged as new treatment options in the management of metastatic $\mathrm{H}$-positive breast cancer in combination with aromatase inhibitors [9-11]. CDK4/6 inhibition attenuates CDK4/6-mediated phosphorylation of retinoblastoma tumor-suppressor protein (RB) and thus maintains RB-E2F interactions leading to G1 cell cycle arrest [12].

Even though therapy with $\mathrm{AI}$ is considered to be well-tolerated, patients receiving AI tend to experience adverse events very often. Aromatase inhibitor-induced arthralgia is estimated to occur in up 50\% of postmenopausal patients, according to a recent meta-analysis [13]. Aromatase inhibitor-induced musculoskeletal symptoms (AIMSS) may present with arthralgia, myalgia, arthritis or stiffness, and it may be the reason for discontinuation of the treatment in approximately $25 \%$ of the patients with early breast cancer [14]. In addition, treatment with $\mathrm{AI}$ resulted in a bone loss rate at least two-fold higher than agematched postmenopausal women increases the risk of fractures [15]. Symptoms typically occur in the upper and lower extremities, mainly in hands and wrists, ankles, shoulders and knees [16]. Given the established benefit of AI treatment in H-positive breast cancer, it is essential to early recognize and better understand aromatase inhibitor-associated musculoskeletal syndrome as well as identify the prevalence of this adverse event. This systematic review summarizes all available data concerning musculoskeletal symptoms reported in randomized Phase III trials evaluating the administration of aromatase inhibitors as a monotherapy or in combination with CDK4/6 inhibitors in the metastatic setting. We aim to clarify the incidence of AIMSS in AI monotherapy treatment in postmenopausal women with metastatic disease and the impact of the recent addition of CDK4/6 inhibitors on this common adverse event. 


\section{Materials and Methods}

\subsection{Search Strategy and Eligibility of Studies}

This systematic review was performed in accordance with PRISMA guidelines [17]. The protocol of this systematic review was submitted to the Institutional Review Board of Alexandra Hospital and Medical School of Athens and is available upon request. Eligible studies were all randomized controlled trials (RCTs) identified using MEDLINE bibliographical and ClinicalTrials.gov database for search concerning the period 2005/01/012021/01/01 so as not to confound data with the combination of AIs and the progestin megestrol acetate that used to be given until then [18-22] or other AIs, e.g., formestane [23]. The search algorithm applied consisted of the following words: (breast AND (cancer OR neoplasm) and (aromatase inhibitors OR letrozole OR anastrozole OR exemestane OR CDK4/6 OR palbociclib OR ribociclib OR abemaciclib) AND (phase III). Language restrictions were not applied. In order to maximize the amount of synthesized information, we systematically examined the reference lists of the articles retrieved for potentially eligible studies.

Eligible studies included all randomized controlled Phase III trials exploring thirdgeneration AI monotherapy treatment in postmenopausal women with locally advanced/ metastatic breast cancer and all randomized controlled Phase III trials evaluating AIs in combination with CDK4/6 inhibitors in postmenopausal patients with advanced or metastatic breast cancer or premenopausal patients that underwent ovarian suppression with GnRH analog, e.g., MONALEESA-7 [24,25]. Phase I-II trials, case reports and reviews were excluded, e.g., FIRST trial [26]. Phase III trials exploring CDK4/6 inhibitors in metastatic breast cancer were considered eligible only when administered in combination with aromatase inhibitors. In addition, trials of AIs administered in combination with other antineoplastic drugs, e.g., trastuzumab, everolimus [27-33] or in combination with bone-protective therapies [34-37], were excluded. Retrospective studies were excluded from this analysis, e.g., the IRIS study [38-40]. In case of overlapping publications emerging from the same study, the larger sample size study was evaluated, e.g., FALCON [41-43]. In case of additional information provided from multiple papers from the same trial, each article was evaluated separately.

\subsection{Data Extraction}

From each of the eligible studies, the following data were extracted: first author, year of publication, trial number, treatment arms, sample size, median age, median follow-up, progression-free survival (PFS), overall survival (OS), number of patients with the bone disease only, arthralgia rate, myalgia rate, bone pain incidence, back pain rate, osteoporosis and osteoporotic fracture rate. Two investigators, working independently, searched the literature and extracted data from each eligible study. Any differences were resolved via within-pair consensus.

\section{Results}

Overall, 535 articles were identified and screened in MEDLINE Database. After the removal of irrelevant and non-eligible articles, 13 studies were considered eligible for our study [9-11,24,41,44-51]. After investigating the references of the eligible articles, one more study was added [52]. An additional search in ClinicalTrial.gov recruited two additional studies $[53,54]$. Overall, 16 studies were considered eligible for this systematic review. The aforementioned stages concerning the selection of studies are illustrated in Figure 1. 


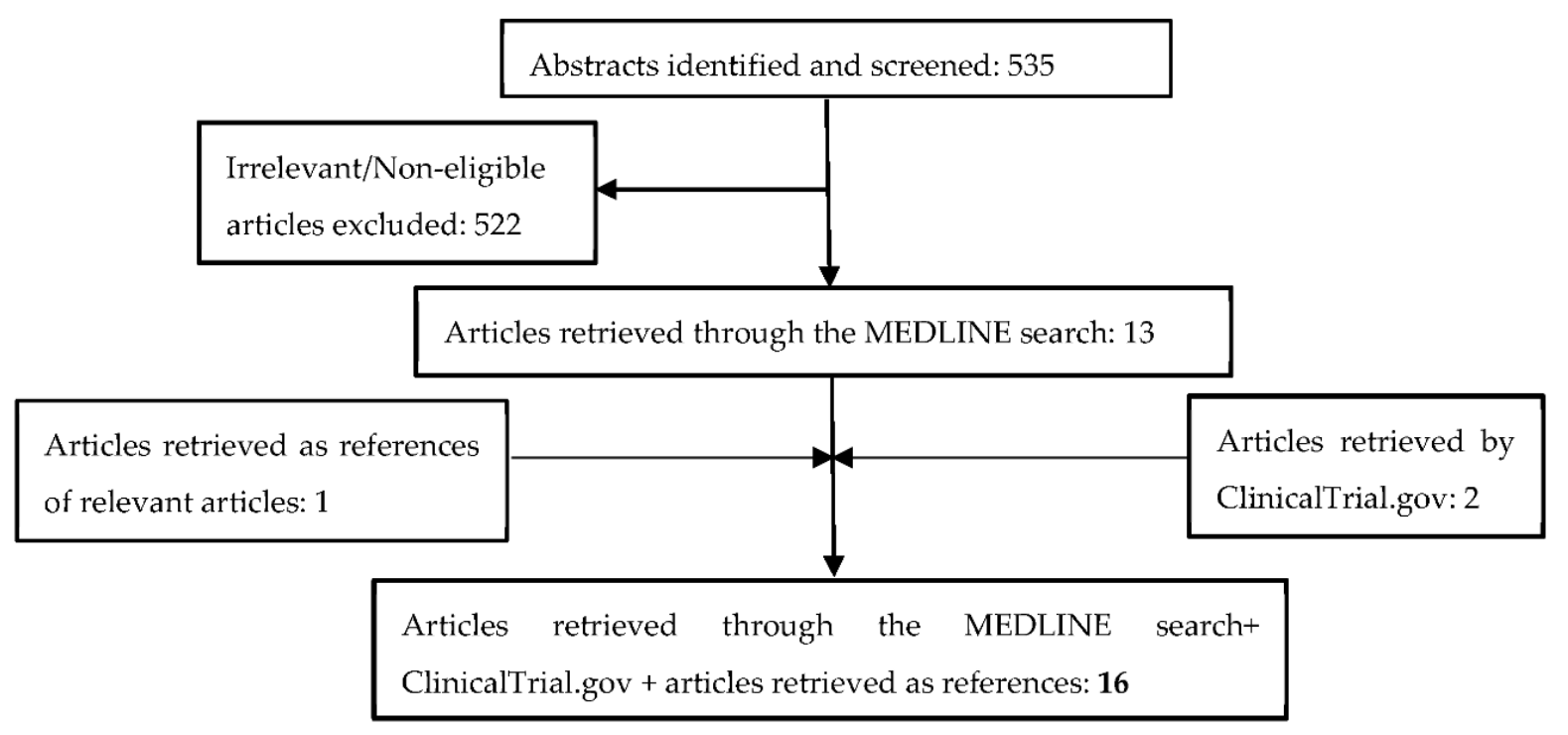

Figure 1. Consort flow diagram according to PRISMA 2009 guidelines.

\subsection{Arthralgia}

In the metastatic setting, the reported percentage of arthralgia in patients under monotherapy with AIs ranged from 1 to $47 \%$ of patients treated with AI as monotherapy vs. $3.7-43 \%$ in patients receiving fulvestrant $[41,44,46-52]$ (Table 1 ). The incidence of arthralgia in the population receiving the combination of fulvestrant plus AI was 12.1-44.5\% [46,49,52]. The arthralgia rate reported in patients receiving exemestane was 5.6-47\% [46-48,50], while anastrozole treatment-induced arthralgia in $1-45.1 \%$ of the cases [41,49-52].

In trials evaluating CDK4/ 6 inhibitor and AI combination treatment, arthralgia was reported in $5.8-33.3 \%$ of patients receiving the combination treatment $[9-11,24,45,53,54]$ (Table 2). The arthralgia rates reported in patients receiving CDK4/ 6 inhibitors plus AIs tend to be lower compared with patients receiving AI monotherapy in the metastatic setting. In the MONALEESA-2 trial, the arthralgia rate was $27.5 \%$ in patients receiving ribociclib with AIs compared with the $28.8 \%$ arthralgia rate in the control arm [9]. This reduction in arthralgia incidence in patients receiving CDK4/6 inhibitors along with endocrine treatment was observed in MONARCHE-3 (12.8\% vs. $16.7 \%)$ and MONARCHE PLUS trials as well $(5.8 \%$ vs. $13.1 \%)[11,53]$. Moreover, palbociclib demonstrated the highest arthralgia rate of the three CDK4/6 inhibitors (33.3\%), while abemaciclib induced the lowest $(5.8 \%-12.8 \%)[10,11,53,54]$. Overall, the addition of CDK4/ 6 inhibitors seems to reduce the arthralgia events induced by monotherapy treatment with AIs.

\subsection{Myalgia}

In trials exploring AIs in metastatic disease, setting the incidence of myalgia reported was $2-23.7 \%$ in patients receiving AIs as monotherapy vs. $2-7 \%$ in fulvestrant monotherapy $[41,46,47,49,50]$ (Table 1). Incidence of myalgias was $3.4-23.7 \%$ in patients treated with anastrozole $[41,49,50]$ compared with $2-4.1 \%$ in patients treated with exemestane $[46,47,50]$.

In Phase III trials exploring CDK $4 / 6$ inhibitors in the metastatic setting, myalgia rate was $4.8-11.9 \%$ in patients receiving CDK4/6 inhibitors and AIs [9-11,24,53,54] (Table 2). The incidence of myalgia was also decreased by the addition of CDK4/ 6 inhibitors to endocrine treatment, consistent with arthralgia rate.

\subsection{Bone Pain}

In the metastatic setting, bone pain was induced in $7-32.9 \%$ of patients treated with AIs monotherapy [46,48,49] (Table 1). Anastrozole induced bone pain in $27.8 \%$ of patients in the SWOG S0226 trial [49], while exemestane induced bone pain in $7-32.9 \%$ of patients in SOFEA and EORTC trials $[46,48,55,56]$. 
The addition of CDK4/6 inhibitors resulted in a $2.9-8.5 \%$ rate of bone pain as reported in Phase III trials [9-11,24,53] (Table 2). Treatment with palbociclib resulted more commonly in bone pain compared with ribociclib or abemaciclib $(8.5 \%$ vs. $7.1-8 \%$ and $2.9-7.9 \%$ ) [9-11,24,53]. Bone pain reported in patients receiving CDK4/6 inhibitors is decreased compared with patients treated with AIs for metastatic disease.

\subsection{Back Pain}

In metastatic disease, back pain was reported in $5.9-40 \%$ of patients treated with AI monotherapy vs. $1-10 \%$ of patients receiving fulvestrant [41,46,49-52] (Table 1). Anastrozole administration resulted in back pain in $5.9-40 \%$ of patients with metastatic breast cancer [41,49-52], whereas exemestane caused back pain in $7-11.4 \%$ of the same population $[46,50]$.

CDK4/ 6 inhibitors caused back pain in 7.8-21.6\% of patients in randomized Phase III trials $[9-11,24,53,54]$ (Table 2). Consistent with the other musculoskeletal symptoms, back pain incidence was higher in patients receiving palbociclib (17.6-21.6\%) compared with ribociclib or abemaciclib treated populations (18.5-20.6\% and 7.8-12.2\% respectively) [9-11,24,53,54]. In addition, back pain was more frequently reported in AI monotherapy treatment (5.9$40 \%$ ) compared with CDK4/6 inhibitor and AI combination treatment (7.8-21.6\%).

\subsection{Osteoporosis-Osteoporotic Fracture}

Osteoporosis incidence failed to reach the frequency threshold of $5 \%$ in trials of both AI monotherapy and CDK4/ 6 inhibitors in the metastatic setting [43,47,48,51,57-61].

Increased fracture susceptibility is considered as one of the most significant adverse events encountered in AI treatment. The incidence of fractures in AI monotherapy in the metastatic disease was rather low (0.2-0.6\%) in the anastrozole-treated population, while there were no fractures reported in the exemestane arm [49,50,55,61] (Table 1). In trials exploring CDK4/6 inhibitors in combination with AIs, fracture rate was $0-0.45 \%$ in the treatment arm $[9,10,24]$ (Table 2). Palbociclib in combination with letrozole resulted in a fracture in $0.45 \%$ of patients enrolled in the PALOMA-2 trial, while no fracture was reported in patients receiving ribociclib plus letrozole in MONALEESA-2 trial and only one patient presented with a fracture in the MONALEESA-7 trial $[9,10,24,57,58]$. No fractures were reported in patients receiving abemaciclib [11,59]. 
Table 1. Phase III randomized trials of aromatase inhibitors (AIs) in postmenopausal women with locally advanced or metastatic breast cancer.

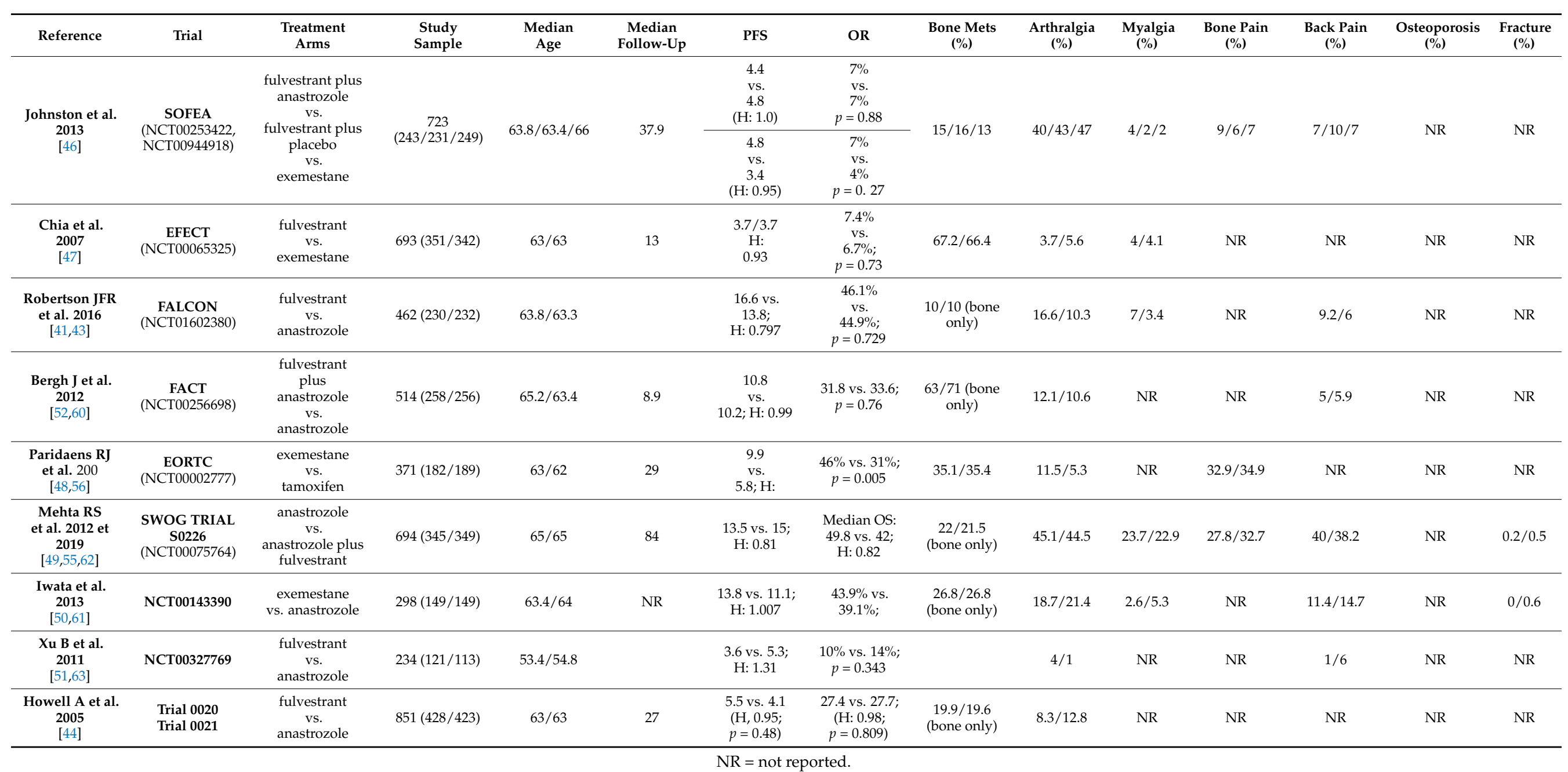


Table 2. Phase III randomized trials of CDK4/6 inhibitors in combination with AIs in postmenopausal women with advanced/metastatic breast cancer.

\begin{tabular}{|c|c|c|c|c|c|c|c|c|c|c|c|c|c|c|}
\hline Reference & Trial & $\begin{array}{c}\text { Treatment } \\
\text { Arms }\end{array}$ & $\begin{array}{c}\text { Study } \\
\text { Sample }\end{array}$ & $\begin{array}{c}\text { Median } \\
\text { Age }\end{array}$ & $\begin{array}{c}\text { Median } \\
\text { Follow-Up }\end{array}$ & PFS & OR & $\begin{array}{c}\text { Bone Mets } \\
\text { Only }\end{array}$ & $\begin{array}{c}\text { Arthralgia } \\
(\%)\end{array}$ & $\begin{array}{c}\text { Myalgia } \\
(\%)\end{array}$ & $\begin{array}{c}\text { Bone } \\
\text { Pain (\%) }\end{array}$ & $\begin{array}{c}\text { Back } \\
\text { Pain (\%) }\end{array}$ & $\begin{array}{l}\text { Osteoporosis } \\
(\%)\end{array}$ & $\begin{array}{c}\text { Fracture } \\
(\%)\end{array}$ \\
\hline $\begin{array}{c}\text { Richard S. Finn } \\
\text { et al. 2016 } \\
{[10,58]}\end{array}$ & $\begin{array}{c}\text { PALOMA-2 } \\
\text { (NCT01740427) }\end{array}$ & $\begin{array}{c}\text { palbociclib plus } \\
\text { letrozole } \\
\text { vs. } \\
\text { letrozole plus placebo }\end{array}$ & $666(444 / 222)$ & $62 / 61$ & 23 & $\begin{array}{c}24.8 / 14.5 \\
\text { (H: } 0.58 ; \\
p<0.001)\end{array}$ & $\begin{array}{l}42.1 / 34.7 \\
(p=0.06)\end{array}$ & 23.2/21.6 & $33.3 / 33.8$ & $11.9 / 9$ & $8.5 / 9$ & 21.6/21.6 & NR & $0.45 / 0$ \\
\hline $\begin{array}{c}\text { Martin et al. } \\
\text { 2020 } \\
{[45,64]}\end{array}$ & $\begin{array}{c}\text { PEARL } \\
\text { (NCT02028507) }\end{array}$ & $\begin{array}{c}\text { Cohort 1: } \\
\text { palbociclib plus } \\
\text { exemestane } \\
\text { vs. } \\
\text { capecitabine } \\
\text { Cohort 2: } \\
\text { palbociclib plus } \\
\text { fulvestrant } \\
\text { vs. } \\
\text { capecitabine }\end{array}$ & $\begin{array}{l}296(153 / 143) \\
305(149 / 156)\end{array}$ & $\begin{array}{l}60 / 60 \\
62 / 60\end{array}$ & $\begin{array}{l}18.9^{*} \\
13.5\end{array}$ & $\begin{array}{l}8 * \text { vs. } 10.6 \\
\text { (H: } 1.11 ; \\
p=0.404) \\
7.5 \text { vs. } 10 \\
\text { (H: } 1.13 ; \\
p=0.398)\end{array}$ & NR & NR & NR & NR & NR & NR & NR & NR \\
\hline $\begin{array}{c}\text { G.N. Hortobagyi } \\
\text { et al. 2016 } \\
{[9,57]}\end{array}$ & $\begin{array}{l}\text { MONALEESA-2 } \\
\text { (NCT01958021) }\end{array}$ & $\begin{array}{l}\text { ribociclib plus letrozole } \\
\text { vs. } \\
\text { placebo plus letrozole }\end{array}$ & $668(334 / 334)$ & $62 / 63$ & 26.4 & $\begin{array}{c}25.3 / 16 \\
\text { (H: } 0.568)\end{array}$ & $\begin{array}{l}\text { 42.5/28.7; } \\
\text { H: } 0.746\end{array}$ & $20.7 / 23.4$ & $27.5 / 28.8$ & $6.5 / 6.3$ & 7.1/10.6 & 20.6/17.8 & NR & $0 / 0.3$ \\
\hline $\begin{array}{c}\text { Tripathy et al. } \\
2018 \\
{[24,25]}\end{array}$ & $\begin{array}{l}\text { MONALEESA-7 } \\
\text { (NCT02278120) }\end{array}$ & $\begin{array}{c}\text { ribociclib plus } \\
\text { tamoxifen/NSAI plus } \\
\text { goserelin } \\
\text { Vs } \\
\text { placebo } \\
\text { plus } \\
\text { tamoxifen/NSAI plus } \\
\text { goserelin }\end{array}$ & $672(335 / 337)$ & $42.6 / 43.7$ & 19.2 & $\begin{array}{l}23.8 \text { vs. } 13 \\
\text { (H: } 0.55 \\
p<0.0001)\end{array}$ & NR & $24.2 / 23.1$ & $29.85 / 27.3$ & $10.1 / 11$ & $8 / 9.5$ & $18.5 / 19.6$ & NR & $0.3 / 0.3$ \\
\hline $\begin{array}{c}\text { Matthew P. } \\
\text { Goetz, 2017 } \\
{[111,59]}\end{array}$ & $\begin{array}{l}\text { MONARCHE-3 } \\
\text { (NCT02246621) }\end{array}$ & $\begin{array}{c}\text { abemaciclib plus } \\
\text { anastrozole or letrozole } \\
\text { vs. } \\
\text { placebo plus } \\
\text { anastrozole or letrozole }\end{array}$ & $493(328 / 165)$ & $63 / 63$ & 26 & $\begin{array}{c}\text { Not } \\
\text { reached vs. } \\
14.7 ; \\
\text { H: } 0.54\end{array}$ & $48.2 / 34.5$ & $21.3 / 23.6$ & $12.8 / 16.7$ & $8.5 / 5.5$ & $7.9 / 7.45$ & $12.2 / 14.9$ & NR & NR \\
\hline \multirow{2}{*}{$\begin{array}{c}\text { NCT02763566 } \\
{[53,65]}\end{array}$} & \multirow{2}{*}{$\begin{array}{l}\text { MONARCHE } \\
\text { PLUS }\end{array}$} & \multirow{2}{*}{$\begin{array}{c}\text { abemaciclib plus NSAI } \\
\text { vs. } \\
\text { placebo plus NSAI } \\
\text { or } \\
\text { abemaciclib plus } \\
\text { fulvestrant } \\
\text { vs. } \\
\text { placebo plus fulvestrant }\end{array}$} & \multirow{2}{*}{$\begin{array}{c}463 \\
(207 / 99 / 104 / 53)\end{array}$} & \multirow{2}{*}{$56 / 59 / 55 / 58$} & \multirow{2}{*}{26} & $\begin{array}{c}\text { Not } \\
\text { reached vs. } \\
14.7 ; \\
\text { H: } 0.49\end{array}$ & $\begin{array}{c}56 / 30 \\
(p<0.0001)\end{array}$ & \multirow{2}{*}{ NR } & $5.8 / 13.1$ & $4.8 / 5$ & $2.9 / 5$ & $7.8 / 9$ & \multirow{2}{*}{ NR } & \multirow{2}{*}{ NR } \\
\hline & & & & & & $\begin{array}{l}11.47 \text { vs. } \\
5.59 ; \\
\text { H: } 0.37\end{array}$ & $\begin{array}{c}38.5 / 7.5 \\
(p<0.0001)\end{array}$ & & $6.7 / 5.6$ & $1.9 / 0$ & $0.9 / 1.8$ & $4.8 / 5.6$ & & \\
\hline $\begin{array}{c}\text { NCT02600923 } \\
{[54]}\end{array}$ & & $\begin{array}{l}\text { palbociclib plus } \\
\text { letrozole }\end{array}$ & 131 & NR & NR & NR & NR & NR & 20 & 6.1 & NR & 17.6 & NR & NR \\
\hline
\end{tabular}




\section{Discussion}

Aromatase inhibitor-induced musculoskeletal syndrome (AIMSS) has emerged as a major cause of treatment discontinuation in hormone receptor-positive patients treated with AIs. In our study, arthralgia was reported in 1-47\% of patients receiving aromatase inhibitors for metastatic breast cancer, while in patients treated with CDK4/6 inhibitors, the arthralgia rate dropped to $5.8-33.3 \%$. According to our review of clinical trial data, it appears that CDK4/6 inhibitors may lead to the mitigation of AIMSS. However, it will be critical to collect more clinical trial data in the future to definitely prove this correlation. Crew et al. reported an incidence of $47 \%$ of joint pain in postmenopausal women treated with $\mathrm{AI}$, including a $23.5 \%$ rate of new-onset joint pain and a $23.5 \%$ rate of exacerbation of preexisting arthralgia [66]. Moreover, joint stiffness was reported in $44 \%$ of the patients enrolled in the study. A recent meta-analysis exploring menopausal symptoms in postmenopausal women showed a $17.9 \%$ rate of arthralgia, ranging from 5.25 to $54.29 \%$ in the studies included [67]. Of note, the incidence of arthralgia was significantly decreased in early-stage breast cancer compared with advanced disease $(R R=0.34,95 \%$ CI: 0.16-0.75) [67]. Overall, approximately $20-47 \%$ of women develop musculoskeletal symptoms during AI therapy, according to previous studies, which is consistent with our results. The upper and lower extremities, mainly hands, wrists, knees and ankles, seem to be the areas most affected by AI treatment [16]. Morales et al. tried to identify the radiological changes of AI-induced joint disease in breast cancer patients [68]. Ultrasound showed fluid accumulation in the tendon sheath surrounding the digital flexor tendons, and MRI demonstrated a thickening of the tendon sheath [68]. Between 6 months and two years, this intra-articular fluid further increased. Both steroidal and nonsteroidal aromatase inhibitors have been associated with AIMSS; however, nonsteroidal AI letrozole had a greater impact on bone mineral density (BMD) of the spine $(p=0.001)$ and hip $(p=0.075)$ than steroidal exemestane [69].

Given the high incidence of arthralgia in AI-treated breast cancer patients, the expected time to onset of symptoms should be identified. In an attempt to shed light on AI-induced musculoskeletal symptoms, a consortium on breast cancer pharmacogenomics (COBRA) trial was conducted in postmenopausal women with early breast cancer [16]. The median time to onset was 1.6 months (range $0.4-10$ months); however, symptoms were reported as early as few days after treatment initiation. An observational study exploring the time course of treatment-related arthralgia reported consistent results (6 weeks until symptom initiation) and a gradual deterioration of symptom severity over 1 year (NCT00954564) [70]. Laroche et al. confirmed the development of joint pain after 6 weeks of treatment and that of a more diffuse pain after 12 months of treatment [71]. Henry et al. reported that the median time to treatment discontinuation due to toxicity was 6 months, while $25 \%$ of patients discontinued therapy due to musculoskeletal symptoms [14]. Collectively, the onset of symptoms occurs most commonly between two to three months from treatment initiation $[16,68,70]$.

Three different mechanisms of AI-induced joint symptoms have been proposed [72] The first and most likely one is based on estrogen deprivation caused by AI treatment. Aromatase inhibitors act by attenuating aromatase systematically even in peripheral tissues like breast and bone, where aromatase maintains local estrogen at reduced levels after menopause. It was shown that anastrozole decreased plasma levels of estrone, estradiol and estrone sulfate by a mean of $81 \%, 84.9 \%$ and $93.5 \%$, while letrozole treatment decreased the same estrogen levels by $84.3 \%, 87.8 \%$ and $98.0 \%$ in postmenopausal women [73]. This decrease of serum estrogen concentrations induced by AI therapy leads to the repression of their bone-protective role within the joint. Estrogen depletion is also associated with an increase in local inflammation, even in the absence of systemic inflammatory markers like C-reactive protein and elevated sedimentation rate. Estrogen receptors, ER $\alpha$ and ER $\beta$, are expressed in human articular chondrocytes and modulate the metabolism of chondrocytes [74]. Women are characterized by lower levels of ER $\alpha$ and ER $\beta$ receptors than men, and thus, they are more prone to cartilage erosion. The existence of estrogen receptors 
on human cartilage indicates the implication of estrogens in the joint microenvironment. Indeed, increased levels of $\operatorname{ER} \alpha$ and $\operatorname{ER} \beta$ have been identified in osteoarthritic joints, suggesting that chondrocytes respond to estrogen signals [75]. Furthermore, estrogens have direct effects on opioid pain fibers in the central nervous system and may affect pain transmission emerging from joint structures [76]. Pain is produced by joint structures innervated with nociceptive fibers like the periosteum, synovium and joint capsule. In the case of arthralgia, inflammatory mediators, including bradykinin and prostaglandins, are secreted to stimulate peripheral nociceptors so that they expand. In this way, nociceptive neurons become more sensitive to peripheral stimuli or central sensitization. Estrogens seem to implicate local inflammation and spinal transmission of pain, though the exact mechanism remains unknown [76]. However, estrogen receptors have been identified in opioid-containing neurons in the spinal cord and brain, further enhancing this notion [76]. Furthermore, it has been suggested that estrogens influence the spinal transmission of nociceptive stimuli through inhibition of microglial activation and inflammatory mediators, including prostaglandin E2 and nitric oxide synthase [75]. Animal studies and estrogen replacement therapy trials suggest a protective role of estrogens in osteoarthritis development $[77,78]$. Consistently, the high prevalence of osteoarthritis around the time of menopause indicates that estrogen depletion may contribute to arthritis development.

Another possible mechanism of treatment-induced musculoskeletal symptoms is through the induction of an autoimmune process that affects the joints, like rheumatoid arthritis [72]. Anastrozole increased the production of proinflammatory cytokines like IFN- $\gamma$, IL-12 and decreased IL-4 and IL-10 cytokine secretion in an animal model that simulates human rheumatoid arthritis $[79,80]$. Treatment with AIs stimulated an inflammatory response by activating CD4+ T cells and suppressing the differentiation of naïve T cells to Tregs that prevent autoimmune responses [79]. In this way, AIs promote the infiltration of the synovial membrane by CD4+ T cells and the cytokine-induced activation of monocytes, macrophages and fibroblasts in the joint microenvironment. Reduction of lymphocyte count, increased natural killer (NK) cell activation, and disruption of the IgG2a/IgG1 balance has been described during AI treatment [80]. Morel et al. described a case of a postmenopausal woman who presented with rheumatoid arthritis after four weeks of exemestane treatment [81]. Symmetric joint involvement, swelling of metacarpophalangeal and interphalangeal joints and increased inflammatory markers should raise the concern of autoimmune-related arthralgia. AIs have been linked to autoimmune diseases, including subacute cutaneous lupus erythematosus (SCLE), cutaneous vasculitis attributed to exemestane and deterioration of preexisting rheumatoid arthritis in a number of cases [80]. Moreover, discontinuation of AI treatment resulted in remission of arthralgia and a decrease in joint pain of over 50\% [82]. Treatment discontinuation also led to the decrease of antinuclear antibodies (ANA) and rheumatoid factor (RF) autoimmune markers. These findings indicate the immunomodulatory effect of AIs as a potential mechanism of AIMSS in multiple cases. Finally, the third mechanism consists of a direct off-target effect of AIs or their metabolites, although this mechanism seems less likely.

Multiple factors influence the incidence of treatment-related arthralgia. High BMI and previous treatment with tamoxifen were shown to have a protective role against arthralgia occurrence $[66,75]$. On the other hand, certain chemotherapeutic drugs like taxanes and longer menopause duration have been associated with increased risk to the development of joint symptoms $[14,66,71]$. In addition, menopausal symptom severity and preexisting joint disease could be used as predictors of arthralgia development [70].

Most inflammatory processes, including arthritis, implicate the STAT3 (signal transducer and activator of transcription) and $\mathrm{NF}_{\kappa} \mathrm{B}$ (nuclear factor $\kappa \mathrm{B}$ ) pathways. Tumor necrosis factor $\alpha$ (TNF- $\alpha$ ), interleukin 1 (IL-1) and IL-6 activate STAT3 and NFkB pathways leading to epithelial cell activation and epithelial-mesenchymal transformation [83]. Estrogens inhibit IL-1 and IL-6-mediated bone absorption and stimulate OPG secretion, while estradiol inhibits osteoblast and stimulates osteoclast apoptosis via TGF- $\beta$ [83]. Estrogen deficiency leads to elevated T-cell induced IL-6 and TNF-a, which are required for 
osteoclast generation [84]. Other proinflammatory cytokines regulating osteoclast production include IL-7, macrophage colony-stimulating factor (M-CSF) and most importantly, receptor activator of nuclear factor-kB ligand (RANKL), which is overexpressed in estrogen deficiency, leading to increased bone resorption. Estrogen loss leads to increased production of RANKL by stromal cells, increased activity of RANK and reduction of osteoprotegerin (OPG), promoting osteoclastogenesis. On the other hand, estrogen binding to ER $\alpha$ on osteoblasts leads to osteoprotegerin (OPG) production, which inhibits TGF- $\beta$ and competitively inhibits RANK/RANKL interactions. As it is known, RANK/RANKL binding activates nuclear factor kappa $\mathrm{B}(\mathrm{NF}-\mathrm{KB})$, resulting in the upregulation of the transcription factor nuclear factor of activated T-cells cytoplasmic 1 (NFATc1). NFATc1 catalyzes the maturation of osteoclast precursors to mature osteoclasts during osteoclastogenesis process.

How CDK4/ 6 inhibitors affect bone metabolism, and AI-related musculoskeletal symptoms is not clear yet. Cyclin-dependent kinases 4 and $6(\mathrm{CDK} 4 / 6)$ regulate cell cycle progression via controlling the phosphorylation of retinoblastoma (RB) protein. In the hypophosphorylated state, RB represses the E2F family of transcription factors that regulate the passage in the $S$ phase, acting as an onco-suppressor that blocks the cell cycle in the G1 phase. However, in response to mitogenic signals, CDK4/6 proteins form a complex with cyclin $\mathrm{D}$, which catalyzes RB phosphorylation and reverses its repressive effect on E2F transcription factors [85]. Upregulation of CDK4/6-RB pathway is common in breast cancer, especially in luminal subtypes, where cyclin D1 amplification is identified in $58 \%$ of luminal B and $29 \%$ of luminal A cancers and CDK4 amplification in $25 \%$ and $14 \%$, respectively [85]. In this way, CDK4/ 6 inhibitors inhibit aberrant cell proliferation by restoring the repressive effect of onco-suppressor RB protein on cell cycle progression. At the same time, CDK4/ 6 inhibitors affect other vital cellular activities. E2Fs consists of a family of transcriptional factors that bind target promoters and regulate gene expression. This family of transcriptional factors consists of both transcription-suppressors, such as E2F4, E2F5 and E2F6 and transcription activators like E2F1, E2F2, E2F3. It was shown that inhibition of E2F expression inhibited the proliferation of synovial cells and prevented cartilage invasion [86]. E2F2 is overexpressed in rheumatoid arthritis synovial tissues indicating a possible association between E2F2 and rheumatoid arthritis [87]. IL-6, TNF- $\alpha$ and LPS stimulate the expression of E2F2 in rheumatoid arthritis synovial fibroblasts via NF- $\mathrm{KB}$, ERK and STAT3 pathway [87]. E2F2, in turn, activates the migration of synovial fibroblasts and the disease progression of RA. Hyperplasia and aberrant secretion of inflammatory factors in synovial fibroblasts leads to joint damage [86]. Another study demonstrated that E2F2 affects the STAT1 pathway and the subsequent activation of the $\mathrm{PI} 3 \mathrm{~K} / \mathrm{AKT} / \mathrm{NF}-\mathrm{KB}$ pathway, which regulates the expression of IL-1 $\alpha$, IL-1 $\beta$ and TNF- $\alpha$ [86]. CDK4/ 6 inhibitors attenuate RB phosphorylation and preserve its suppressive effect on E2F transcriptional factors. Considering that arthritis and arthralgia are based on a complex inflammatory process, CDK4/6 inhibitors may attenuate E2F2 activity in synovium and cartilage and reverse, at least in part, the inflammation caused by aromatase inhibitors.

Recently, single nucleotide polymorphisms (SNPs) within genes controlling estrogen metabolism or signaling have been linked to AI-related arthralgia. SNPs in the CYP19A1 gene encoding the aromatase enzyme have been associated with an increased risk of arthralgia in patients treated with AIs. Park I.H. et al. associated a specific haplotype M_3_5 of the CYP19A1 gene composed of 16 SNPs with arthralgia incidence $(p=0.01)$ [88]. A subanalysis of the TEAM trial identified the homozygous variant rs934635 genotype of the CYP19A1 gene as a risk factor of musculoskeletal toxicity [89]. Other genetic variants of the CYP19A1 gene have also been associated with an increased incidence of arthralgia and bone loss after treatment with AIs [90,91]. In addition, Estrogen receptor 1 (ESR1) and ESR2 gene polymorphisms have been linked to treatment-related arthralgia [92]. Patients with ESR1 SNP rs2077647 variants exhibited lower rates of joint toxicity, while those with ESR2 SNP rs4986938 rare allele were at increased risk of arthralgia. Consistently, Henry et al. reported an increased discontinuation rate due to joint pain in patients with the genetic ESR1 variant rs9322336 [93]. Moreover, Garcia-Giralt et al. conducted a cohort 
study to evaluate the clinical role of SNPs within genes involved in estrogen and vitamin D metabolism. SNPs in steroid 17-alpha-hydroxylase/17,20 lyase (CYP17A1) and vitamin D3 receptor (VDR) genes were significantly associated with treatment-related arthralgia ( $p=0.003$ and $p=0.012$, respectively) [94]. The clinical effect of these gene SNPs during treatment with CDK4/6 inhibitors is not yet characterized. The mitigation of AIMSS observed during CDK4/6 inhibitor administration may be partly attributed to currently unknown SNPs. Inversely, the SNPs previously described may predispose to the increased arthralgia observed in AI monotherapy.

\section{Conlusions}

We report an incidence of AI-induced musculoskeletal symptoms similar to the incidence described in previous studies and meta-analyses. The addition of CDK4/6 inhibitors in previous treatment with AIs tends to improve the incidence of this adverse event. More data from ongoing studies in the adjuvant and metastatic setting remain to clarify the effect of CDK4/6 inhibition on musculoskeletal symptoms.

Funding: This research did not receive any specific grant from funding agencies in the public, commercial, or not-for-profit sectors.

Institutional Review Board Statement: Not applicable.

Informed Consent Statement: Not applicable.

Data Availability Statement: All data can be found in MEDLINE bibliographical dataset.

Conflicts of Interest: M.L. has received honoraria from Roche, Astra Zeneca, Astellas, MSD, Janssen, Bristol-Myers-Squibb and IPSEN. M.-A.D. has received honoraria from participation in advisory boards from Amgen, Bristol-Myers-Squibb, Celgene, Janssen, Takeda. F.Z. has received honoraria for lectures and has served in an advisory role for Astra-Zeneca, Daiichi, Eli-Lilly, Merck, Novartis, Pfizer, and Roche. The remaining authors declare no conflicts of interest.

\section{References}

1. Siegel, R.L.; Miller, K.D.; Jemal, A. Cancer statistics, 2020. CA Cancer J. Clin. 2020, 70, 7-30. [CrossRef]

2. Howlader, N.; Altekruse, S.F.; Li, C.I.; Chen, V.W.; Clarke, C.A.; Ries, L.A.G.; Cronin, K.A. US incidence of breast cancer subtypes defined by joint hormone receptor and HER2 status. J. Natl. Cancer Inst. 2014, 106. [CrossRef]

3. Zhang, X.H.F.; Giuliano, M.; Trivedi, M.V.; Schiff, R.; Kent Osborne, C. Metastasis dormancy in estrogen receptor-positive breast cancer. Clin. Cancer Res. 2013, 19, 6389-6397. [CrossRef]

4. Li, J.; Huo, X.; Zhao, F.; Ren, D.; Ahmad, R.; Yuan, X.; Du, F.; Zhao, J. Association of Cyclin-Dependent Kinases 4 and 6 Inhibitors with Survival in Patients with Hormone Receptor-Positive Metastatic Breast Cancer. JAMA Netw. Open 2020, 3, e2020312. [CrossRef]

5. Goss, P.E.; Ingle, J.N.; Pritchard, K.I.; Robert, N.J.; Muss, H.; Gralow, J.; Gelmon, K.; Whelan, T.; Strasser-Weippl, K.; Rubin, S.; et al. Extending Aromatase-Inhibitor Adjuvant Therapy to 10 Years. N. Engl. J. Med. 2016, 375, 209-219. [CrossRef] [PubMed]

6. Regan, M.M.; Price, K.N.; Giobbie-Hurder, A.; Thürlimann, B.; Gelber, R.D. Interpreting breast international group (BIG) 1-98: A randomized, double-blind, phase III trial comparing letrozole and tamoxifen as adjuvant endocrine therapy for postmenopausal women with hormone receptor-positive, early breast cancer. Breast Cancer Res. 2011, 13, 209. [CrossRef] [PubMed]

7. Coombes, R.; Kilburn, L.; Snowdon, C.; Paridaens, R.; Coleman, R.; Jones, S.; Jassem, J.; Van de Velde, C.; Delozier, T.; Alvarez, I.; et al. Survival and safety of exemestane versus tamoxifen after 2-3 years' tamoxifen treatment (Intergroup Exemestane Study): A randomised controlled trial. Lancet 2007, 369, 559-570. [CrossRef]

8. Jeselsohn, R.; Buchwalter, G.; De Angelis, C.; Brown, M.; Schiff, R. ESR1 mutations-a mechanism for acquired endocrine resistance in breast cancer. Nat. Rev. Clin. Oncol. 2015, 12, 573-583. [CrossRef] [PubMed]

9. Hortobagyi, G.N.; Stemmer, S.M.; Burris, H.A.; Yap, Y.S.; Sonke, G.S.; Paluch-Shimon, S.; Campone, M.; Petrakova, K.; Blackwell, K.L.; Winer, E.P.; et al. Updated results from MONALEESA-2, a phase III trial of first-line ribociclib plus letrozole versus placebo plus letrozole in hormone receptor-positive, HER2-negative advanced breast cancer. Ann. Oncol. 2018, 29, $1541-1547$. [CrossRef] [PubMed]

10. Finn, R.S.; Martin, M.; Rugo, H.S.; Jones, S.; Im, S.-A.; Gelmon, K.; Harbeck, N.; Lipatov, O.N.; Walshe, J.M.; Moulder, S.; et al. Palbociclib and Letrozole in Advanced Breast Cancer. N. Engl. J. Med. 2016, 375, 1925-1936. [CrossRef] [PubMed]

11. Goetz, M.P.; Toi, M.; Campone, M.; Trédan, O.; Bourayou, N.; Sohn, J.; Park, I.H.; Paluch-Shimon, S.; Huober, J.; Chen, S.C.; et al. MONARCH 3: Abemaciclib as initial therapy for advanced breast cancer. J. Clin. Oncol. 2017, 35, 3638-3646. [CrossRef] [PubMed] 
12. Klein, M.E.; Kovatcheva, M.; Davis, L.E.; Tap, W.D.; Koff, A. CDK4/6 Inhibitors: The Mechanism of Action May Not Be as Simple as Once Thought. Cancer Cell 2018, 34, 9-20. [CrossRef] [PubMed]

13. Beckwée, D.; Leysen, L.; Meuwis, K.; Adriaenssens, N. Prevalence of aromatase inhibitor-induced arthralgia in breast cancer: A systematic review and meta-analysis. Support. Care Cancer 2017, 25, 1673-1686. [CrossRef] [PubMed]

14. Henry, N.L.; Azzouz, F.; Desta, Z.; Li, L.; Nguyen, A.T.; Lemler, S.; Hayden, J.; Tarpinian, K.; Yakim, E.; Flockhart, D.A.; et al. Predictors of aromatase inhibitor discontinuation as a result of treatment-emergent symptoms in early-stage breast cancer. J. Clin. Oncol. 2012, 30, 936-942. [CrossRef]

15. Hadji, P. Aromatase inhibitor-associated bone loss in breast cancer patients is distinct from postmenopausal osteoporosis. Crit. Rev. Oncol. Hematol. 2009, 69, 73-82. [CrossRef] [PubMed]

16. Henry, N.L.; Giles, J.T.; Ang, D.; Mohan, M.; Dadabhoy, D.; Robarge, J.; Hayden, J.; Lemler, S.; Shahverdi, K.; Powers, P.; et al. Prospective characterization of musculoskeletal symptoms in early stage breast cancer patients treated with aromatase inhibitors. Breast Cancer Res. Treat. 2008, 111, 365-372. [CrossRef]

17. Liberati, A.; Altman, D.G.; Tetzlaff, J.; Mulrow, C.; Gøtzsche, P.C.; Ioannidis, J.P.A.; Clarke, M.; Devereaux, P.J.; Kleijnen, J.; Moher, D. The PRISMA statement for reporting systematic reviews and meta-analyses of studies that evaluate health care interventions: Explanation and elaboration. J. Clin. Epidemiol. 2009, 62, e1-e34. [CrossRef]

18. Buzdar, A.; Douma, J.; Davidson, N.; Elledge, R.; Morgan, M.; Smith, R.; Porter, L.; Nabholtz, J.; Xiang, X.; Brady, C. Phase III, multicenter, double-blind, randomized study of letrozole, an aromatase inhibitor, for advanced breast cancer versus megestrol acetate. J. Clin. Oncol. 2001, 19, 3357-3366. [CrossRef]

19. Kaufmann, M.; Bajetta, E.; Dirix, L.Y.; Fein, L.E.; Jones, S.E.; Zilembo, N.; Dugardyn, J.L.; Nasurdi, C.; Mennel, R.G.; Cervek, J.; et al. Exemestane is superior to megestrol acetate after tamoxifen failure in postmenopausal women with advanced breast cancer: Results of a phase III randomized double-blind trial. J. Clin. Oncol. 2000, 18, 1399-1411. [CrossRef]

20. Buzdar, A.; Jonat, W.; Howell, A.; Jones, S.E.; Blomqvist, C.; Vogel, C.L.; Eiermann, W.; Wolter, J.M.; Azab, M.; Webster, A.; et al. Anastrozole, a potent and selective aromatase inhibitor, versus megestrol acetate in postmenopausal women with advanced breast cancer: Results of overview analysis of two phase III trials. J. Clin. Oncol. 1996, 14, 2000-2011. [CrossRef] [PubMed]

21. Dombernowsky, P.; Smith, I.; Falkson, G.; Leonard, R.; Panasci, L.; Bellmunt, J.; Bezwoda, W.; Gardin, G.; Gudgeon, A.; Morgan, M.; et al. Letrozole, a new oral aromatase inhibitor for advanced breast cancer: Double-blind randomized trial showing a dose effect and improved efficacy and tolerability compared with megestrol acetate. J. Clin. Oncol. 1998, 16, 453-461. [CrossRef] [PubMed]

22. Jonat, W.; Howell, A.; Blomqvist, C.; Eiermann, W.; Winblad, G.; Tyrrell, C.; Mauriac, L.; Roche, H.; Lundgren, S.; Hellmund, R.; et al. A randomised trial comparing two doses of the new selective aromatase inhibitor anastrozole (Arimidex)* with megestrol acetate in postmenopausal patients with advanced breast cancer. Eur. J. Cancer 1996, 32, 404-412. [CrossRef]

23. Freue, M.; Kjaer, M.; Boni, C.; Joliver, J.; Jänicke, F.; Willemse, H.B.; Coombes, R.C.; Van Belle, S.; Pérez-Carrión, R.; Zieschang, J.; et al. Open comparative trial of formestane versus megestrol acetate in postmenopausal patients with advanced breast cancer previously treated with tamoxifen. Breast 2000, 9, 9-16. [CrossRef] [PubMed]

24. Tripathy, D.; Im, S.A.; Colleoni, M.; Franke, F.; Bardia, A.; Harbeck, N.; Hurvitz, S.A.; Chow, L.; Sohn, J.; Lee, K.S.; et al. Ribociclib plus endocrine therapy for premenopausal women with hormone-receptor-positive, advanced breast cancer (MONALEESA-7): A randomised phase 3 trial. Lancet Oncol. 2018, 19, 904-915. [CrossRef]

25. Study of Efficacy and Safety in Premenopausal Women with Hormone Receptor Positive, HER2-Negative Advanced Breast Cancer Full Text View ClinicalTrials.gov. Available online: https:/ / linicaltrials.gov/ct2/show / NCT02278120?term=ribociclib\& cond $=$ Breast + Cancer \&draw $=6 \&$ rank $=43$ (accessed on 9 January 2021).

26. Ellis, M.J.; Llombart-Cussac, A.; Feltl, D.; Dewar, J.A.; Jasiówka, M.; Hewson, N.; Rukazenkov, Y.; Robertson, J.F.R. Fulvestrant $500 \mathrm{mg}$ versus anastrozole $1 \mathrm{mg}$ for the first-line treatment of advanced breast cancer: Overall survival analysis from the phase II first study. J. Clin. Oncol. 2015, 33, 3781-3786. [CrossRef] [PubMed]

27. Dickler, M.N.; Barry, W.T.; Cirrincione, C.T.; Ellis, M.J.; Moynahan, M.E.; Innocenti, F.; Hurria, A.; Rugo, H.S.; Lake, D.E.; Hahn, O.; et al. Phase III trial evaluating letrozole as first-line endocrine therapy with or without bevacizumab for the treatment of postmenopausal women with hormone receptor-positive advanced-stage breast cancer: CALGB 40503 (Alliance). J. Clin. Oncol. 2016, 34, 2602-2609. [CrossRef] [PubMed]

28. Huober, J.; Fasching, P.A.; Barsoum, M.; Petruzelka, L.; Wallwiener, D.; Thomssen, C.; Reimer, T.; Paepke, S.; Azim, H.A.; Ragosch, V.; et al. Higher efficacy of letrozole in combination with trastuzumab compared to letrozole monotherapy as first-line treatment in patients with HER2-positive, hormone-receptor-positive metastatic breast cancer Results of the eLEcTRA trial. Breast 2012, 21, 27-33. [CrossRef]

29. Wolff, A.C.; Lazar, A.A.; Bondarenko, I.; Garin, A.M.; Brincat, S.; Chow, L.; Sun, Y.; Neskovic-Konstantinovic, Z.; Guimaraes, R.C.; Fumoleau, P.; et al. Randomized phase III placebo-controlled trial of letrozole plus oral temsirolimus as first-line endocrine therapy in postmenopausal women with locally advanced or metastatic breast cancer. J. Clin. Oncol. 2013, 31, 196-202. [CrossRef]

30. Pritchard, K.I.; Burris, H.A.; Ito, Y.; Rugo, H.S.; Dakhil, S.; Hortobagyi, G.N.; Campone, M.; Csöszi, T.; Baselga, J.; Puttawibul, P.; et al. Safety and efficacy of everolimus with exemestane vs. Exemestane alone in elderly patients with HER2-negative, hormone receptor-positive breast cancer in BOLERO-2. Clin. Breast Cancer 2013, 13, 421-432.e8. [CrossRef]

31. Falandry, C.; Debled, M.; Bachelot, T.; Delozier, T.; Crétin, J.; Romestaing, P.; Mille, D.; You, B.; Mauriac, L.; Pujade-Lauraine, E.; et al. Celecoxib and exemestane versus placebo and exemestane in postmenopausal metastatic breast cancer patients: A double-blind phase III GINECO study. Breast Cancer Res. Treat. 2009, 116, 501-508. [CrossRef] 
32. Martín, M.; Loibl, S.; Von Minckwitz, G.; Morales, S.; Martinez, N.; Guerrero, A.; Anton, A.; Aktas, B.; Schoenegg, W.; Muñoz, M.; et al. Phase III trial evaluating the addition of bevacizumab to endocrine therapy as first-line treatment for advanced breast cancer:The Letrozole/Fulvestrant and Avastin (LEA) study. J. Clin. Oncol. 2015, 33, 1045-1052. [CrossRef] [PubMed]

33. Kaufman, B.; Mackey, J.R.; Clemens, M.R.; Bapsy, P.P.; Vaid, A.; Wardley, A.; Tjulandin, S.; Jahn, M.; Lehle, M.; Feyereislova, A.; et al. Trastuzumab plus anastrozole versus anastrozole alone for the treatment of postmenopausal women with human epidermal growth factor receptor 2-positive, hormone receptor-positive metastatic breast cancer: Results from the randomized phase III TAnDEM study. J. Clin. Oncol. 2009, 27, 5529-5537. [CrossRef] [PubMed]

34. Van Poznak, C.; Hannon, R.A.; Mackey, J.R.; Campone, M.; Apffelstaedt, J.P.; Clack, G.; Barlow, D.; Makris, A.; Eastell, R. Prevention of aromatase inhibitor-induced bone loss using risedronate: The SABRE trial. J. Clin. Oncol. 2010, 28, 967-975. [CrossRef] [PubMed]

35. Markopoulos, C.; Tzoracoleftherakis, E.; Polychronis, A.; Venizelos, B.; Dafni, U.; Xepapadakis, G.; Papadiamantis, J.; Zobolas, V.; Misitzis, J.; Kalogerakos, K.; et al. Management of anastrozole-induced bone loss in breast cancer patients with oral risedronate: Results from the ARBI prospective clinical trial. Breast Cancer Res. 2010, 12, R24. [CrossRef]

36. Wagner-Johnston, N.D.; Sloan, J.A.; Liu, H.; Kearns, A.E.; Hines, S.L.; Puttabasavaiah, S.; Dakhil, S.R.; Lafky, J.M.; Perez, E.A.; Loprinzi, C.L. 5-year follow-up of a randomized controlled trial of immediate versus delayed zoledronic acid for the prevention of bone loss in postmenopausal women with breast cancer starting letrozole after tamoxifen: N03CC (Alliance) trial. Cancer 2015, 121, 2537-2543. [CrossRef]

37. Gnant, M.; Pfeiler, G.; Dubsky, P.C.; Hubalek, M.; Greil, R.; Jakesz, R.; Wette, V.; Balic, M.; Haslbauer, F.; Melbinger, E.; et al. Adjuvant denosumab in breast cancer (ABCSG-18): A multicentre, randomised, double-blind, placebo-controlled trial. Lancet 2015, 386, 433-443. [CrossRef]

38. Taylor-Stokes, G.; Mitra, D.; Waller, J.; Gibson, K.; Milligan, G.; Iyer, S. Treatment patterns and clinical outcomes among patients receiving palbociclib in combination with an aromatase inhibitor or fulvestrant for HR+/HER2-negative advanced/metastatic breast cancer in real-world settings in the US: Results from the IRIS study. Breast 2019, 43, 22-27. [CrossRef]

39. Ibrance Real World Insights Full Text View ClinicalTrials.gov. Available online: https:/ / clinicaltrials.gov/ct2/show / NCT03159 195?term=palbociclib+PD-0332991\&cond=Breast+Cancer\&draw=15\&rank=133 (accessed on 9 January 2021).

40. Waller, J.; Mitra, D.; Mycock, K.; Taylor-Stokes, G.; Milligan, G.; Zhan, L.; Iyer, S. Real-world treatment patterns and clinical outcomes in patients receiving palbociclib for hormone receptor-positive, human epidermal growth factor receptor 2-negative advanced or metastatic breast cancer in Argentina: The IRIS study. J. Glob. Oncol. 2019, 2019. [CrossRef]

41. Robertson, J.F.R.; Bondarenko, I.M.; Trishkina, E.; Dvorkin, M.; Panasci, L.; Manikhas, A.; Shparyk, Y.; Cardona-Huerta, S.; Cheung, K.L.; Philco-Salas, M.J.; et al. Fulvestrant $500 \mathrm{mg}$ versus anastrozole $1 \mathrm{mg}$ for hormone receptor-positive advanced breast cancer (FALCON): An international, randomised, double-blind, phase 3 trial. Lancet 2016, 388, 2997-3005. [CrossRef]

42. Noguchi, S.; Ellis, M.J.; Robertson, J.F.R.; Thirlwell, J.; Fazal, M.; Shao, Z. Progression-free survival results in postmenopausal Asian women: Subgroup analysis from a phase III randomized trial of fulvestrant $500 \mathrm{mg}$ vs anastrozole $1 \mathrm{mg}$ for hormone receptor-positive advanced breast cancer (FALCON). Breast Cancer 2018, 25, 356-364. [CrossRef]

43. A Global Study to Compare the Effects of Fulvestrant and Arimidex in a Subset of Patients with Breast Cancer. Study Results ClinicalTrials.gov. Available online: https:/ / clinicaltrials.gov/ct2/show / results / NCT01602380?term=aromatase+inhibitors+ phase $+3 \&$ cond $=$ Breast + Cancer\&draw $=17$ (accessed on 14 November 2020).

44. Howell, A.; Pippen, J.; Elledge, R.M.; Mauriac, L.; Vergote, I.; Jones, S.E.; Come, S.E.; Osborne, C.K.; Robertson, J.F.R. Fulvestrant versus anastrozole for the treatment of advanced breast carcinoma: A prospectively planned combined survival analysis of two multicenter trials. Cancer 2005, 104, 236-239. [CrossRef] [PubMed]

45. Martin, M.; Zielinski, C.; Ruiz-Borrego, M.; Carrasco, E.; Turner, N.; Ciruelos, E.M.; Muñoz, M.; Bermejo, B.; Margeli, M.; Anton, A.; et al. Palbociclib in combination with endocrine therapy versus capecitabine in hormonal receptor-positive, human epidermal growth factor 2-negative, aromatase inhibitor-resistant metastatic breast cancer: A phase III randomised controlled trial-PEARL. Ann. Oncol. 2020. [CrossRef]

46. Johnston, S.R.D.; Kilburn, L.S.; Ellis, P.; Dodwell, D.; Cameron, D.; Hayward, L.; Im, Y.H.; Braybrooke, J.P.; Brunt, A.M.; Cheung, K.L.; et al. Fulvestrant plus anastrozole or placebo versus exemestane alone after progression on non-steroidal aromatase inhibitors in postmenopausal patients with hormone-receptor-positive locally advanced or metastatic breast cancer (SoFEA): A composite, multicentre, phase 3 randomised trial. Lancet Oncol. 2013, 14, 989-998. [CrossRef]

47. Chia, S.; Gradishar, W.; Mauriac, L.; Bines, J.; Amant, F.; Federico, M.; Fein, L.; Romieu, G.; Buzdar, A.; Robertson, J.F.R.; et al. Double-blind, randomized placebo controlled trial of fulvestrant compared with exemestane after prior nonsteroidal aromatase inhibitor therapy in postmenopausal women with hormone receptor-positive, advanced breast cancer: Rsults from EFECT. J. Clin. Oncol. 2008, 26, 1664-1670. [CrossRef] [PubMed]

48. Paridaens, R.J.; Dirix, L.Y.; Beex, L.V.; Nooij, M.; Cameron, D.A.; Cufer, T.; Piccart, M.J.; Bogaerts, J.; Therasse, P. Phase III study comparing exemestane with tamoxifen as first-line hormonal treatment of metastatic breast cancer in postmenopausal women: The European Organisation for Research and Treatment of Cancer Breast Cancer Cooperative Group. J. Clin. Oncol. 2008, 26, 4883-4890. [CrossRef] [PubMed] 
49. Mehta, R.S.; Barlow, W.E.; Albain, K.S.; Vandenberg, T.A.; Dakhil, S.R.; Tirumali, N.R.; Lew, D.L.; Hayes, D.F.; Gralow, J.R.; Livingston, R.B.; et al. Combination Anastrozole and Fulvestrant in Metastatic Breast Cancer. N. Engl. J. Med. 2012, 367, 435-444. [CrossRef]

50. Iwata, H.; Masuda, N.; Ohno, S.; Rai, Y.; Sato, Y.; Ohsumi, S.; Hashigaki, S.; Nishizawa, Y.; Hiraoka, M.; Morimoto, T.; et al. A randomized, double-blind, controlled study of exemestane versus anastrozole for the first-line treatment of postmenopausal Japanese women with hormone-receptor-positive advanced breast cancer. Breast Cancer Res. Treat. 2013, 139, 441-451. [CrossRef]

51. Xu, B.; Jiang, Z.; Shao, Z.; Wang, J.; Feng, J.; Song, S.; Chen, Z.; Gu, K.; Yu, S.; Zhang, Y.; et al. Fulvestrant 250 mg versus anastrozole for Chinese patients with advanced breast cancer: Results of a multicentre, double-blind, randomised phase III trial. Cancer Chemother. Pharmacol. 2011, 67, 223-230. [CrossRef]

52. Bergh, J.; Jönsson, P.E.; Lidbrink, E.K.; Trudeau, M.; Eiermann, W.; Brattström, D.; Lindemann, J.P.O.; Wiklund, F.; Henriksson, R. FACT: An open-label randomized phase III study of fulvestrant and anastrozole in combination compared with anastrozole alone as first-line therapy for patients with receptor-positive postmenopausal breast cancer. J. Clin. Oncol. 2012, 30, 1919-1925. [CrossRef]

53. A Study of Abemaciclib (LY2835219) in Participants with Breast Cancer Study Results ClinicalTrials.gov. Available online: https: / / clinicaltrials.gov/ct2/show / results / NCT02763566?term=aromatase+inhibitors + phase $+3 \&$ cond=Breast + Cancer\& draw $=8 \&$ rank=66 (accessed on 14 November 2020).

54. Palbociclib Plus Letrozole For Postmenopausal Women with HR(+) HER2(-) Advanced Breast Cancer For Whom Letrozole is Deemed Appropriate Full Text View ClinicalTrials.gov. Available online: https:/ / clinicaltrials.gov/ct2/show /NCT02600923? term $=$ NCT02600923\&draw=2\&rank=1 (accessed on 14 November 2020).

55. Mehta, R.S.; Barlow, W.E.; Albain, K.S.; Vandenberg, T.A.; Dakhil, S.R.; Tirumali, N.R.; Lew, D.L.; Hayes, D.F.; Gralow, J.R.; Linden, H.M.; et al. Overall Survival with Fulvestrant plus Anastrozole in Metastatic Breast Cancer. N. Engl. J. Med. 2019, 380, 1226-1234. [CrossRef]

56. Exemestane Compared with Tamoxifen in Treating Women with Locally Recurrent or Metastatic Breast Cancer Full Text View ClinicalTrials.gov. Available online: https:/ / clinicaltrials.gov/ct2/show /NCT00002777?term=aromatase+inhibitors+phase+ $3 \&$ cond $=$ Breast + Cancer\&draw $=22$ (accessed on 14 November 2020).

57. Study of Efficacy and Safety of LEE011 in Postmenopausal Women with Advanced Breast Cancer.(MONALEESA-2) Full Text View ClinicalTrials.gov. Available online: https: / clinicaltrials.gov / ct2 / show / NCT01958021?term=NCT01958021\&draw=2\&rank=1 (accessed on 12 November 2020).

58. A Study of Palbociclib (PD-0332991) + Letrozole vs. Letrozole for 1st Line Treatment of Postmenopausal Women with ER+/HER2Advanced Breast Cancer (PALOMA-2) Study Results ClinicalTrials.gov. Available online: https://clinicaltrials.gov/ct2/show / results $/$ NCT01740427?term $=$ NCT01740427\&draw=2\&rank=1 (accessed on 14 November 2020).

59. A Study of Nonsteroidal Aromatase Inhibitors Plus Abemaciclib (LY2835219) in Postmenopausal Women with Breast Cancer Study Results ClinicalTrials.gov. Available online: https: / clinicaltrials.gov / ct2/ show / results / NCT02246621?term=NCT02246 $621 \&$ draw $=2$ (accessed on 14 November 2020).

60. Anastrozole Monotherapy versus Maximal Oestrogen Blockade with Anastrozole and Fulvestrant Combination Therapy Study Results ClinicalTrials.gov. Available online: https: / clinicaltrials.gov/ct2/show/results / NCT00256698?term=aromatase+ inhibitors+phase+3\&cond=Breast+Cancer\&draw=19\&rank=179\&view=results (accessed on 14 November 2020).

61. Aromasin vs. Arimidex Study as Initial Hormonal Therapy in Postmenopausal Women with Advanced/Recurrent Breast Cancer Study Results ClinicalTrials.gov. Available online: https:/ / clinicaltrials.gov/ct2/show / results /NCT00143390?term=exemestane+ phase $+3 \&$ cond $=$ Breast + Cancer $\&$ draw $=6 \&$ rank $=44$ (accessed on 14 November 2020).

62. S0226 Anastrozole with or without Fulvestrant as First-Line Therapy in Postmenopausal Women with Metastatic Breast Cancer Study Results ClinicalTrials.gov. Available online: https: / clinicaltrials.gov/ct2/show / results / NCT00075764?term=aromatase + inhibitors+phase+3\&cond=Breast+Cancer\&draw=13\&view=results (accessed on 14 November 2020).

63. Faslodex Advanced Breast Cancer Local Chinese Study Full Text View ClinicalTrials.gov. Available online: https:/ / clinicaltrials.gov / ct2/show /NCT00327769? term=anastrozole+phase+3\&cond=Breast+Cancer\&draw=5\&rank=39 (accessed on 14 November 2020).

64. Phase III Palbociclib with Endocrine Therapy vs. Capecitabine in HR+/HER2-MBC with Resistance to Aromatase Inhibitors Full Text View ClinicalTrials.gov. Available online: https:/ / clinicaltrials.gov/ct2/show/study/NCT02028507?term=palbociclib+PD0332991\&cond=Breast + Cancer\&draw $=10 \% 5 C$ (accessed on 9 January 2021).

65. Zhang, Q.Y.; Sun, T.; Yin, Y.M.; Li, H.P.; Yan, M.; Tong, Z.S.; Oppermann, C.P.; Liu, Y.P.; Costa, R.; Li, M.; et al. MONARCH plus: Abemaciclib plus endocrine therapy in women with HR+/HER2- advanced breast cancer: The multinational randomized phase III study. Ther. Adv. Med. Oncol. 2020, 12. [CrossRef] [PubMed]

66. Crew, K.D.; Greenlee, H.; Capodice, J.; Raptis, G.; Brafman, L.; Fuentes, D.; Sierra, A.; Hershman, D.L. Prevalence of joint symptoms in postmenopausal women taking aromatase inhibitors for early-stage breast cancer. J. Clin. Oncol. 2007, 25, 3877-3883. [CrossRef] [PubMed]

67. Dongsheng, H.; Ling, B.; Jun, Z.; Yinghui, T.; Qingwei, Z.; Jing, C.; Xiaoyang, L. Incidence of menopausal symptoms in postmenopausal breast cancer patients treated with aromatase inhibitors. Oncotarget 2017, 8, 40558-40567. [CrossRef]

68. Morales, L.; Pans, S.; Paridaens, R.; Westhovens, R.; Timmerman, D.; Verhaeghe, J.; Wildiers, H.; Leunen, K.; Amant, F.; Berteloot, P.; et al. Debilitating musculoskeletal pain and stiffness with letrozole and exemestane: Associated tenosynovial changes on magnetic resonance imaging. Breast Cancer Res. Treat. 2007, 104, 87-91. [CrossRef] 
69. Oesterreich, S.; Henry, N.L.; Kidwell, K.M.; Van Poznak, C.H.; Skaar, T.C.; Dantzer, J.; Li, L.; Hangartner, T.N.; Peacock, M.; Nguyen, A.T.; et al. Associations between genetic variants and the effect of letrozole and exemestane on bone mass and bone turnover. Breast Cancer Res. Treat. 2015, 154, 263-273. [CrossRef]

70. Castel, L.D.; Hartmann, K.E.; Mayer, I.A.; Saville, B.R.; Alvarez, J.; Boomershine, C.S.; Abramson, V.G.; Chakravarthy, A.B.; Friedman, D.L.; Cella, D.F. Time course of arthralgia among women initiating aromatase inhibitor therapy and a postmenopausal comparison group in a prospective cohort. Cancer 2013, 119, 2375-2382. [CrossRef]

71. Laroche, F.; Coste, J.; Medkour, T.; Cottu, P.H.; Pierga, J.Y.; Lotz, J.P.; Beerblock, K.; Tournigand, C.; Declèves, X.; De Cremoux, P.; et al. Classification of and risk factors for estrogen deprivation pain syndromes related to aromatase inhibitor treatments in women with breast cancer: A prospective multicenter cohort study. J. Pain 2014, 15, 293-303. [CrossRef]

72. Henry, N.L.; Giles, J.T. Vered Stearns Aromatase inhibitor-associated musculoskeletal symptoms: Etiology and strategies for management. Breast Cancer 2008, 22, 12.

73. Geisler, J.; Haynes, B.; Anker, G.; Dowsett, M.; Lønning, P.E. Influence of Letrozole and Anastrozole on Total Body Aromatization and Plasma Estrogen Levels in Postmenopausal Breast Cancer Patients Evaluated in a Randomized, Cross-Over Study. J. Clin. Oncol. 2002, 20, 751-757. [CrossRef]

74. Ushiyama, T.; Ueyama, H.; Inoue, K.; Ohkubo, I.; Hukuda, S. Expression of genes for estrogen receptors $\alpha$ and $\beta$ in human articular chondrocytes. Osteoarthr. Cartil. 1999, 7, 560-566. [CrossRef]

75. Coleman, R.E.; Bolten, W.W.; Lansdown, M.; Dale, S.; Jackisch, C.; Merkel, D.; Maass, N.; Hadji, P. Aromatase inhibitor-induced arthralgia: Clinical experience and treatment recommendations. Cancer Treat. Rev. 2008, 34, 275-282. [CrossRef]

76. Felson, D.T.; Cummings, S.R. Aromatase inhibitors and the syndrome of arthralgias with estrogen deprivation. Arthritis Rheum. 2005, 52, 2594-2598. [CrossRef]

77. Nevitt, M.C.; Cummings, S.R.; Lane, N.E.; Hochberg, M.C.; Scott, J.C.; Pressman, A.R.; Genant, H.K.; Cauley, J.A. Association of estrogen replacement therapy with the risk of osteoarthritis of the hip in elderly white women. Arch. Intern. Med. 1996, 156, 2073-2080. [CrossRef]

78. Spector, T.D.; Nandra, D.; Hart, D.J.; Doyle, D.V. Is hormone replacement therapy protective for hand and knee osteoarthritis in women?: The Chingford Study. Ann. Rheum. Dis. 1997, 56, 432-434. [CrossRef] [PubMed]

79. Jingxuan, W.; Qingyuan, Z.; Shi, J.; Meiyan, F.; Xinmei, K.; Shu, Z.; Shuling, L.; Wenhui, Z. Immoderate inhibition of estrogen by anastrozole enhances the severity of experimental polyarthritis. Exp. Gerontol. 2009, 44, 398-405. [CrossRef] [PubMed]

80. Zarkavelis, G.; Kollas, A.; Kampletsas, E.; Vasiliou, V.; Kaltsonoudis, E.; Drosos, A.; Khaled, H.; Pavlidis, N. Aromatase inhibitors induced autoimmune disorders in patients with breast cancer: A review. J. Adv. Res. 2016, 7, 719-726. [CrossRef]

81. Morel, B.; Marotte, H.; Miossec, P. Will steroidal aromatase inhibitors induce rheumatoid arthritis? Ann. Rheum. Dis. 2007, 66, 557-558. [CrossRef]

82. Laroche, M.; Seniow, M.; Roche, H.; Ruyssen-Witrand, A. Arthralgia associated with autoimmune abnormalities under aromatase inhibitor therapy: Outcome after cessation of treatment. J. Rheumatol. 2016, 43, 1945-1946. [CrossRef] [PubMed]

83. Szekanecz, Z.; Gomez, I.; Soós, B.; Bodoki, L.; Szamosi, S.; András, C.; Juhász, B.; Váróczy, L.; Antal-Szalmás, P.; Szodoray, P.; et al. Eight pillars of oncorheumatology: Crossroads between malignancies and musculoskeletal diseases. Autoimmun. Rev. 2020, 19, 102658. [CrossRef] [PubMed]

84. Carlsten, H. Immune responses and bone loss: The estrogen connection. Immunol. Rev. 2005, 208, 194-206. [CrossRef]

85. Murphy, C.G.; Dickler, M.N. The Role of CDK4/6 Inhibition in Breast Cancer. Oncologist 2015, 20, 483-490. [CrossRef]

86. Wang, S.; Wang, L.; Wu, C.; Sun, S.; Pan, J.H. E2F2 directly regulates the STAT1 and PI3K/AKT/NF-kB pathways to exacerbate the inflammatory phenotype in rheumatoid arthritis synovial fibroblasts and mouse embryonic fibroblasts. Arthritis Res. Ther. 2018, 20, 225. [CrossRef]

87. Zhang, R.; Wang, L.; Pan, J.H.; Han, J. A critical role of E2F transcription factor 2 in proinflammatory cytokines-dependent proliferation and invasiveness of fibroblast-like synoviocytes in rheumatoid Arthritis. Sci. Rep. 2018, 8. [CrossRef]

88. Park, I.H.; Lee, Y.S.; Lee, K.S.; Kim, S.Y.; Hong, S.H.; Jeong, J.; Lee, H.; Ro, J.; Nam, B.H. Single nucleotide polymorphisms of CYP19A1 predict clinical outcomes and adverse events associated with letrozole in patients with metastatic breast cancer. Cancer Chemother. Pharmacol. 2011, 68, 1263-1271. [CrossRef]

89. Fontein, D.B.Y.; Houtsma, D.; Nortier, J.W.R.; Baak-Pablo, R.F.; Kranenbarg, E.M.K.; Van Der Straaten, T.R.J.H.M.; Putter, H.; Seynaeve, C.; Gelderblom, H.; Van De Velde, C.J.H.; et al. Germline variants in the CYP19A1 gene are related to specific adverse events in aromatase inhibitor users: A substudy of Dutch patients in the TEAM trial. Breast Cancer Res. Treat. 2014, 144, 599-606. [CrossRef]

90. Mao, J.J.; Su, H.I.; Feng, R.; Donelson, M.L.; Aplenc, R.; Rebbeck, T.R.; Stanczyk, F.; DeMichele, A. Association of functional polymorphisms in CYP19A1 with aromatase inhibitor associated arthralgia in breast cancer survivors. Breast Cancer Res. 2011, 13. [CrossRef]

91. Napoli, N.; Rastelli, A.; Ma, C.; Yarramaneni, J.; Vattikutti, S.; Moskowitz, G.; Giri, T.; Mueller, C.; Kulkarny, V.; Qualls, C.; et al. Genetic polymorphism at Val80 (rs700518) of the CYP19A1 gene is associated with aromatase inhibitor associated bone loss in women with ER (+) breast cancer. Bone 2013, 55, 309-314. [CrossRef]

92. Leyland-Jones, B.; Gray, K.P.; Abramovitz, M.; Bouzyk, M.; Young, B.; Long, B.; Kammler, R.; Dell'Orto, P.; Biasi, M.O.; Thürlimann, B.; et al. ESR1 and ESR2 polymorphisms in the BIG 1-98 trial comparing adjuvant letrozole versus tamoxifen or their sequence for early breast cancer. Breast Cancer Res. Treat. 2015, 154, 543-555. [CrossRef] [PubMed] 
93. Henry, N.L.; Skaar, T.C.; Dantzer, J.; Li, L.; Kidwell, K.; Gersch, C.; Nguyen, A.T.; Rae, J.M.; Desta, Z.; Oesterreich, S.; et al. Genetic associations with toxicity-related discontinuation of aromatase inhibitor therapy for breast cancer. Breast Cancer Res. Treat. 2013, 138, 807-816. [CrossRef] [PubMed]

94. Garcia-Giralt, N.; Rodríguez-Sanz, M.; Prieto-Alhambra, D.; Servitja, S.; Torres-Del Pliego, E.; Balcells, S.; Albanell, J.; Grinberg, D.; Diez-Perez, A.; Tusquets, I.; et al. Genetic determinants of aromatase inhibitor-related arthralgia: The B-ABLE cohort study. Breast Cancer Res. Treat. 2013, 140, 385-395. [CrossRef] 